Jurnal Teknologi Pertanian Vol. 19 No. 2 [Agustus 2018] 75-84

Potensi Jali (Coix lachryma-jobi L.) Sebagai Prebiotik [Husna dkk]

\title{
POTENSI JALI (COIX LACHRYMA-JOBI L.) SEBAGAI PREBIOTIK TERHADAP PERTUMBUHAN BAKTERI ASAM LAKTAT
}

\author{
Potency of Adlay (Coix lachryma-jobi L.) as Prebiotic on The Growth of \\ Lactic Acid Bacteria
}

\author{
Afifa Husna, Devi arianty, Aji Sutrisno, Agustin Krisna Wardani* \\ Jurusan Teknologi Hasil Pertanian - Fakultas Teknologi Pertanian - Universitas Brawijaya \\ Jalan Veteran, Malang 65145 \\ *Penulis Korespondensi: email: wardani8@yahoo.com
}

\begin{abstract}
ABSTRAK
Jali (Coix lachryma-jobi L.) adalah sumber karbohidrat yang keberadaannya belum dimanfaatkan secara maksimal oleh masyarakat Indonesia. Di luar negeri, jali telah banyak dimanfaatkan sebagai tanaman obat karena mengandung banyak senyawa fungsional, salah satunya adalah polisakarida yang berfungsi sebagai prebiotik. Polisakarida biasanya didapatkan dengan cara ekstraksi menggunakan pelarut air bersuhu tinggi. Tujuan penelitian ini adalah melakukan ekstraksi polisakarida pada jali dengan faktor suhu dan lama ekstraksi untuk mendapatkan ekstrak polisakarida dengan hasil rendemen tertinggi, yang akan diuji manfaatnya sebagai prebiotik secara in vitro. Penelitian ini menggunakan Response Surface Methodology dengan rancangan komposit pusat dua faktor, yakni suhu $\left(75,90\right.$, dan $\left.105^{\circ} \mathrm{C}\right)$ dan lama ekstraksi $(150,210$, dan 270 menit), serta satu respon yaitu jumlah rendemen ekstrak (\%). Pengujian prebiotik dilakukan menggunakan bakteri Bifidobacterium bifidum dan Lactobacillus casei yang ditumbuhkan pada media dengan penambahan ekstrak polisakarida sebesar 0,1 , dan $2 \%$. Optimasi ekstraksi polisakarida pada jali memiliki rendemen tertinggi pada suhu $85.45^{\circ} \mathrm{C}$ dan lama ekstraksi 207.63 menit, yaitu sebesar 3.29\%. Ekstrak ini juga diketahui berpotensi sebagai prebiotik karena dapat meningkatkan pertumbuhan kedua bakteri, serta dapat mempertahankan keberadaannya pada konsentrasi penambahan $2 \%$ ekstrak dalam media pertumbuhan mikroba
\end{abstract}

Kata kunci : Bifidobacterium bifidum, Jali, Lactobacillus casei, Polisakarida, Prebiotik

\begin{abstract}
Adlays (Coix lachryma-jobi L.) is one of a local grain crop that have a high carbohydate content. Their existance is not being maximally utilized yet in Indonesia. In many foreign countries, adlay are called food supplement because it has a lot of functional subtances, such as polysaccharides, and have the ability as prebiotics and can be extracted by hot water extraction method. The purpose of this study is to extract polysaccharide with temperature and time as the variable for getting the maximum yield extract. This study conducted by Response Surface Methodology with central composite design two factorial, that was temperature $\left(75,90\right.$, and $\left.105^{\circ} \mathrm{C}\right)$ and time extraction $(150,210$, and 270 minutes). The optimum point then were verified and analyzed its prebiotic activity on L. casei and B. bifidum in a media supplemented with 0 , 1 , and $2 \%$ of polysaccharide extract. The optimization of polysaccharide extraction reached maximum yield at $85.45^{\circ} \mathrm{C}$ and 207.63 minutes, that was $3.2863 \%$. The prebiotic test found that polysaccharide extract could increase the growth of both probiotics in the media supplemented with $1 \%$ and $2 \%$ extract. This extract could also maintain their existence during 36 hours of fermentation process
\end{abstract}

Keywords : Adlay, Bifidobacterium bifidum, Lactobacillus casei, Polysaccharide, Prebiotic 
Jurnal Teknologi Pertanian Vol. 19 No. 2 [Agustus 2018] 75-84

Potensi Jali (Coix lachryma-jobi L.) Sebagai Prebiotik [Husna dkk]

\section{PENDAHULUAN}

Jali (Coix lachryma-jobi L.) adalah tanaman serelia yang berasal dari Asia timur dan Malaya, namun sekarang sudah tersebar luas diseluruh dunia (Mjwara dan Botha, 1993; Kutschera and Krasaekoopt, 2012; Chen et al., 2016; Hong et al., 2016). Tanaman ini merupakan sumber karbohidrat, lemak, serat, dan antioksidan yang sudah banyak digunakan sebagai makanan pokok masyarakat di dunia. Jali diketahui mempunyai kandungan karbohidrat yang tinggi yaitu sebesar $76.4 \%$, serta kandungan kalsium yang lebih tinggi dibandingkan beras, jagung, dan sorgum yaitu sebesar $54 \mathrm{mg}$ per $100 \mathrm{~g}$ (Nurmala, 2011). Nutrisi jali yang tinggi ini pada kenyataannya belum mampu menekan ketergantungan masyarakat terhadap beras sebagai makanan pokok, yakni sebesar $139 \mathrm{~kg}$ per kapita (Badan Pusat Statistik, 2011). Oleh karena itu, jali diharapkan menjadi salah satu alternatif untuk pengganti beras sebagai makanan pokok.

Jali pada beberapa negara telah banyak dimanfaatkan sebagai tanaman obat. Hal ini dikarenakan jali merupakan tanaman yang mengandung senyawa-senyawa fungsional yang mempunyai manfaat bagi tubuh manusia, salah satunya adalah polisakarida (Lu et al., 2013; Yu et al., 2011; Yu et al., 2012; Apirattananusorn, 2007). Polisakarida dalam jali berfungsi sebagai prebiotik karena tidak dapat dicerna oleh enzim perncernaan manusia, dapat dimanfaatkan sebagai substrat untuk menstimulasi pertumbuhan dan aktivitas mikrobiota usus, mengatasi diare hingga mencegah kanker kolon (Kuo et al., 2012; Lam dan Cheung, 2013; Chang et al., 2018). Selama ini untuk memperoleh senyawa polisakarida dapat dilakukan dengan proses ekstraksi menggunakan pelarut air dengan suhu yang tinggi. Menurut Azmi et al. (2012) ekstraksi polisakarida menggunakan pelarut air dengan suhu tinggi dan lama waktu ekstraksi yang panjang menyebabkan proses ekstraksi semakin optimal untuk menghasilkan rendemen yang tinggi dan menghilangkan senyawa pengotor seperti protein dan lemak.

Berdasarkan uraian tersebut, maka pada penelitian ini akan dikaji proses ekstraksi polisakarida dari jali terkait faktor suhu dan lama ekstraksi untuk mendapatkan ekstrak polisakarida dengan hasil rendemen tertinggi. Selanjutnya, hasil ekstrak polisakarida dilakukan proses pengujian aktivitas prebiotik secara in vitro pada bakteri probiotik, seperti Lactobacillus casei dan Bifidobacterium bifidum. Hasil dari penelitian ini diharapkan dapat memberikan informasi tentang jali sebagai sumber polisakarida dan kemampuan polisakarida tersebut sebagai prebiotik yang menguntungkan bagi kesehatan, sehingga meningkatkan daya guna jali yang selama ini kurang termanfaatkan.

\section{BAHAN DAN METODE}

\section{Bahan}

Bahan utama yang digunakan pada penelitian adalah biji jali sosoh yang didapat dari toko Lai-Lai Malang. Bahan kimia yang digunakan adalah aquades, etanol 75\% dan 80\% (Merck, PA), HCl 25\% (Merck, $\mathrm{PA}$ ), $\mathrm{NaOH} 45 \%$ (Merck, $\mathrm{PA}$ ), $\mathrm{K}_{2} \mathrm{SO}_{4}$ (Merck, PA), $\mathrm{H}_{2} \mathrm{SO}_{4}$ (Merck, PA), asam borat $\mathrm{H}_{2} \mathrm{BO}_{3}$ (Merck, PA). Kultur mikroba yang digunakan adalah Lactobacillus casei FNCC 0090 dan Bifidobacterium bifidum ATCC 12746 yang didapatkan dari PAU Pangan dan Gizi Universitas Gadjah Mada. Bahan pembuatan media pertumbuhan mikroba adalah MRSB (Himedia) dan MRSA (Merck), alkohol 70\% (Merck).

\begin{abstract}
Alat
Alat yang digunakan meliputi waterbath (Memmert WNB 14), rotary evaporator (IKA RV 10 Digital), centrifuge (Hettich Zentrifugen EBA 20), hotplate stirer (Fisher), timbangan analitik (Mettler Toledo), erlenmeyer, labu ukur, blender, pengayak 60 mesh, kertas saring halus, dan corong.

\section{Metode \\ Ekstraksi Polisakarida Jali}

Biji jali dihaluskan dengan blender hingga halus, kemudian diayak dengan ayakan 60 mesh. Bubuk jali yang telah halus dimasukkan pada erlenmeyer dan ditambahkan 80\% etanol dengan rasio 9:1 (v/v), kemudian dipanaskan pada hotplate stirer selama 5 jam. Setelah itu, campuran disaring menggunakan kertas saring halus untuk didapatkan residunya, kemudian ditambahkan pelarut air ke dalam residu tersebut $(20: 1 \mathrm{v} / \mathrm{v})$ dan diinkubasi dalam waterbath yang telah diatur suhunya $75,90,105^{\circ} \mathrm{C}$ selama 150,210 , dan 270 menit, dilanjutkan dengan penyaringan dengan kertas saring halus. Filtrat kemudian disentrifugasi selama 1 menit pada $4000 \mathrm{rpm}$,
\end{abstract}


dan supernatan diambil. Setelah itu, dilakukan evaporasi vakum pada suhu $60^{\circ} \mathrm{C}$ sampai didapatkan ekstrak pekat, kemudian dilakukan proses presipitasi menggunakan etanol dingin 75\% dengan rasio 3:1 dan dikeringkan dengan oven pada suhu $40{ }^{\circ} \mathrm{C}$ selama 48 jam (Azmi et al., 2012; Lu et al., 2013) .

Rendemen hasil ekstrak polisakarida dilanjutkan dengan karakteristik sifat kimia dan mikrobiologi meliputi kadar air metode oven, kadar protein metode makro Kjeldahl, kadar lemak dan kadar serat kasar (AOAC, 2005), kadar pati metode hidrolisis asam (Apriyantono et al., 1989), kemampuannya sebagai prebiotik (Wang et al., 2015).

\section{Rancangan Penelitian}

Rancangan penelitian ini dianalisis dengan menggunakan perangkat lunak Design Expert 7.1.6 Trial Version (Stat-Ease, Inc., Minneapolis, USA) menggunakan Response Surface Methodology (RSM), dengan rancangan komposit pusat. Data yang didapatkan kemudian dianalisis meliputi ketepatan model dan sumber keragaman (ANOVA). Prediksi titik optimum yang didapatkan kemudian diverifikasi untuk mendapatkan rendemen tertinggi.

\section{HASIL DAN PEMBAHASAN}

\section{Analisis Bahan Baku}

Data analisis karakteristik bahan baku biji jali sosoh ditunjukkan dalam Tabel 1 . Berdasarkan data pada Tabel 1 menunjukkan bahwa bahan baku biji jali menghasilkan sedikit perbedaan dibandingkan data dari penelitian yang dilakukan oleh Gänzle dan Follador (2012) dan Cruz (2014). Hasil penelitian menunjukkan nilai yang lebih rendah dibandingkan literatur untuk kadar protein, lemak dan pati. Adanya perbedaan tersebut bisa disebabkan karena beberapa hal seperti letak geografis maupun iklim. Selain itu, kondisi dan lama penyimpanan juga dapat mempengaruhi komposisi kimia yang mengakibatkan terjadi susut bobot pada jali. Susut bobot tersebut akan menyebabkan perubahan pada kandungan pati dan serat kasar (Gänzle dan Follador, 2012; Yu et al., 2011; Yu et al., 2012).

\section{Optimasi Proses Ekstraksi Polisakarida Jali} Data optimasi proses ekstraksi dapat dilihat pada Tabel 2. Hasil analisis menyatakan model kuadratik lebih disarankan daripada model lain. Berdasarkan Tabel 3, model kuadratik memiliki nilai $\mathrm{p}=0.0036$ yang menunjukkan bahwa peluang kesalahan model kurang dari 5\%, sehingga model ini ditetapkan sebagai model terpilih. Berdasarkan perhitungan ketidaktepatan model (Lack of Fit Test) pada Tabel 4, model kuadratik dinyatakan sebagai model terpilih, karena model tersebut memiliki nilai $\mathrm{p}=0.0922$ yang menunjukkan kesalahan model ini tidak berbeda nyata $(p>5 \%)$. Tabel 5 menunjukkan bahwa model yang terpilih sebagai model yang tepat adalah model kuadratik karena model kuadratik memiliki nilai $\mathrm{R}^{2}$, adjusted $\mathrm{R}^{2}$, dan predicted $R^{2}$ yang paling tinggi, serta variabel suhu dan lama ekstraksi berpengaruh terhadap respon nilai rendemen sebesar $74.23 \%$. Berdasarkan ketiga metode evaluasi model yang telah dilakukan, dapat disimpulkan bahwa model yang terpilih untuk menjelaskan hubungan antara kedua variabel terhadap respon adalah model kuadratik.

Berdasarkan analisis ANOVA pada Tabel 6, model variabel suhu ekstraksi pada grafik kuadratik memberikan pengaruh yang signifikan terhadap respon rendemen polisakarida ( $>5 \%$ ). Pada variabel lama ekstraksi menunjukkan nilai $\mathrm{p}$ yang lebih besar dari $5 \%$, sehingga variabel ini tidak menunjukkan pengaruh yang signifikan terhadap respon rendemen polisakarida. Hal ini diduga karena rentang antar level yang digunakan terlalu kecil, karena perlakuan kenaikan suhu masih belum dapat memberikan pengaruh terhadap respon rendemen. Berdasarkan hal tersebut, persamaan regresi model kuadratik dari respon $Y$ yang dipengaruhi oleh $X_{1}$ dan $X_{2}$ yang ditunjukkan pada Persamaan 1 .

$$
\begin{aligned}
& \mathrm{Y}=44.599-1.0564 \mathrm{X}_{1}-0.0266 \mathrm{X}_{2}+1.1389 .10^{-5} \mathrm{X}_{1} \mathrm{X}_{2} \\
& +0.0062 X_{1}^{2}+6.1719 X_{2}^{2}
\end{aligned}
$$

Pada Gambar 1(a), plot kontur menunjukkan kontur dan kurva respon yang dipengaruhi oleh variabel. Sumbu dan pada kontur menunjukkan variabel yang dioptimasi, sedangkan garis-garis melingkar menunjukkan respon. Semakin dekat pada daerah yang berwarna merah maka titik tersebut memiliki respon yang semakin tinggi.

Pada Gambar 1(b), grafik 3D menunjukkan bahwa pengaruh suhu dan lama ekstraksi bersifat kuadratik terhadap respon rendemen polisakarida. Gambar tersebut 
Jurnal Teknologi Pertanian Vol. 19 No. 2 [Agustus 2018] 75-84

Potensi Jali (Coix lachryma-jobi L.) Sebagai Prebiotik [Husna dkk]

Tabel 1. Parameter sifat kimia jali

\begin{tabular}{lcc}
\hline Parameter & Hasil analisis $\mathbf{( b b )}$ & Literatur \\
\hline Kadar Air (\%) & $9.51 \pm 0.52$ & $10.6^{\mathrm{a}}$ \\
Protein (\%) & $8.28 \pm 0.96$ & $12.1^{\mathrm{a}}$ \\
Lemak (\%) & $0.53 \pm 0.05$ & $6.3^{\mathrm{a}}$ \\
Pati (\%) & $63.66 \pm 0.43$ & $73.9^{\mathrm{b}}$ \\
Serat kasar (\%) & $1.05 \pm 0.44$ & $1.8^{\mathrm{a}}$ \\
\hline
\end{tabular}

Keterangan: ${ }^{\mathrm{a} G a ̈ n z l e ~ d a n ~ F o l l a d o r ~(2012) ; ~}{ }^{\mathrm{b} C r u z ~(2014)}$

Tabel 2. Rendemen polisakarida hasil ekstraksi

\begin{tabular}{cccccc}
\hline \multirow{2}{*}{ No } & \multicolumn{2}{c}{ Variabel terkode } & \multicolumn{2}{c}{ Variabel asli } & Respon \\
\cline { 2 - 6 } & $\mathbf{X}_{1}$ & $\mathbf{X}_{2}$ & Suhu $\left({ }^{\circ} \mathbf{C}\right)$ & $\begin{array}{c}\text { Lama } \\
\text { (menit) }\end{array}$ & Rendemen Polisakarida ('Y,\%) \\
\hline 1 & 0 & 0 & 90 & 210 & 3.896 \\
2 & 0 & 0 & 90 & 210 & 2.837 \\
3 & 0 & 0 & 90 & 210 & 2.916 \\
4 & 0 & 0 & 90 & 210 & 3.298 \\
5 & 0 & 0 & 90 & 210 & 2.917 \\
6 & 0 & 1.41 & 90 & 294.85 & 2.746 \\
7 & 0 & -1.41 & 90 & 125.15 & 2.864 \\
8 & -1 & -1 & 75 & 150 & 2.878 \\
9 & -1 & 1 & 75 & 270 & 2.898 \\
10 & 1 & -1 & 105 & 150 & 0.088 \\
11 & 1 & 1 & 105 & 270 & 0.067 \\
12 & -1.41 & 0 & 68.79 & 210 & 0.867 \\
13 & 1.41 & 0 & 111.2 & 210 & 0.081 \\
\hline
\end{tabular}

Tabel 3. Hasil analisis sequential model of sum squares pada optimasi proses ekstraksi polisakarida jali

\begin{tabular}{lcccccc}
\hline $\begin{array}{l}\text { Sumber } \\
\text { Keragaman }\end{array}$ & $\begin{array}{c}\text { Jumlah } \\
\text { Kuadrat }\end{array}$ & $\begin{array}{c}\text { Derajat } \\
\text { Bebas }\end{array}$ & $\begin{array}{c}\text { Rerata } \\
\text { Kuadrat } \\
\text { Tengah }\end{array}$ & Nilai F & $\begin{array}{c}p \text {-value } \\
\text { Prob }>F\end{array}$ & Keterangan \\
\hline Mean vs Total & 61.7986 & 1 & 61.7986 & & & \\
Linear vs Mean & 5.6695 & 2 & 2.8347 & 1.6890 & 0.2334 & \\
2FI vs Linear & 0.0004 & 1 & 0.0004 & 0.0002 & 0.9884 & \\
Quadratic vs 2FI & $\underline{13.4080}$ & $\underline{2}$ & $\underline{6.7040}$ & $\underline{13.9042}$ & $\underline{0.0036}$ & Suggested \\
Cubic vs Quadratic & 2.5453 & 2 & 1.2727 & 7.6686 & 0.0300 & Aliased \\
Residual & 0.8298 & 5 & 0.1660 & & & \\
Total & 84.2516 & 13 & 6.4809 & & & \\
\hline
\end{tabular}


Tabel 4. Hasil analisis lack of fit test optimasi proses ekstraksi polisakarida jali

\begin{tabular}{lcccccl}
\hline $\begin{array}{l}\text { Sumber } \\
\text { Keragaman }\end{array}$ & $\begin{array}{c}\text { Jumlah } \\
\text { Kuadrat }\end{array}$ & $\begin{array}{c}\text { Derajat } \\
\text { Bebas }\end{array}$ & $\begin{array}{c}\text { Kuadrat } \\
\text { Tengah }\end{array}$ & Nilai F & p-value Prob $>$ F & Keterangan \\
\hline Linear & 16.0029 & 6 & 2.6671 & 13.6664 & 0.0122 & \\
2FI & 16.0025 & 5 & 3.2005 & 16.3992 & 0.0090 & \\
Quadratic & $\underline{2.5944}$ & $\underline{3}$ & $\underline{0.8648}$ & $\underline{4.4313}$ & $\underline{0.0922}$ & $\underline{\text { Suggested }}$ \\
Cubic & 0.0491 & 1 & 0.0491 & 0.2518 & 0.6422 & Aliased \\
Pure Error & 0.7806 & 4 & 0.1952 & & & \\
\hline
\end{tabular}

Tabel 5. Hasil analisis model summary statistics optimasi proses ekstraksi polisakarida jali

\begin{tabular}{lcccccl}
\hline $\begin{array}{l}\text { Sumber } \\
\text { Keragaman }\end{array}$ & Std. Dev. & $\mathbf{R}^{2}$ & Adj. $\mathbf{R}^{2}$ & Pred. $\mathbf{R}^{2}$ & PRESS & Keterangan \\
\hline Linear & 1.2955 & 0.2525 & 0.1030 & -0.3881 & 31.1672 & \\
2FI & 1.3656 & 0.2525 & 0.0034 & -0.8726 & 42.0446 & \\
Quadratic & $\underline{0.6944}$ & $\underline{0.8497}$ & $\underline{0.7423}$ & $\underline{0.1240}$ & $\underline{19.6692}$ & $\underline{\text { Suggested }}$ \\
Cubic & 0.4074 & 0.9630 & 0.9113 & 0.8056 & 4.3648 & Aliased \\
\hline
\end{tabular}

Tabel 6. Hasil analisis ragam (ANOVA) respon rendemen polisakarida

\begin{tabular}{lcccccl}
\hline $\begin{array}{l}\text { Sumber } \\
\text { Keragaman }\end{array}$ & $\begin{array}{c}\text { Jumlah } \\
\text { Kuadrat }\end{array}$ & $\begin{array}{c}\text { Derajat } \\
\text { Bebas }\end{array}$ & $\begin{array}{c}\text { Rerata } \\
\text { Kuadrat } \\
\text { Tengah }\end{array}$ & Nilai F & $\begin{array}{c}\text { Nilai } \\
\text { Prob }>\text { P }\end{array}$ & Keterangan \\
\hline Model & 19.0779 & 5 & 3.8156 & 7.9136 & 0.0085 & Signifikan \\
A-Suhu & 5.6659 & 1 & 5.6659 & 11.7513 & 0.0110 & Signifikan \\
B-Lama & 0.0035 & 1 & 0.0035 & 0.0073 & 0.9343 & Tidak signifikan \\
AB & 0.0004 & 1 & 0.0004 & 0.0009 & 0.9773 & Tidak signifikan \\
A $^{2}$ & 13.3960 & 1 & 13.3960 & 27.7835 & 0.0012 & Signifikan \\
B $^{2}$ & 0.3434 & 1 & 0.3434 & 0.7123 & 0.4266 & Tidak Signifikan \\
Residual & 3.3751 & 7 & 0.4822 & & & \\
Lack of Fit & 2.5944 & 3 & 0.8648 & 4.4313 & 0.0922 & Tidak signifikan \\
Pure Error & 0.7806 & 4 & 0.1952 & & & \\
Cor Total & 22.4530 & 12 & & & & \\
\hline
\end{tabular}

Tabel 7. Prediksi titik optimum dan verifikasi hasil optimasi proses ekstraksi polisakarida jali

\begin{tabular}{lccccc}
\hline & $\begin{array}{c}\text { Suhu } \\
\left({ }^{\circ} \mathrm{C}\right)\end{array}$ & $\begin{array}{c}\text { Lama } \\
(\mathbf{m e n i t})\end{array}$ & $\begin{array}{c}\text { Rendemen } \\
(\mathbf{\%})\end{array}$ & Des. & Keterangan \\
\hline Prediksi & 85.44 & 207.63 & 3.299 & 0.8441 & Selected \\
Verifikasi & 85.4 & 207.6 & 3.286 & & \\
Ketepatan $(\%)$ & & & 99.615 & & \\
\hline
\end{tabular}




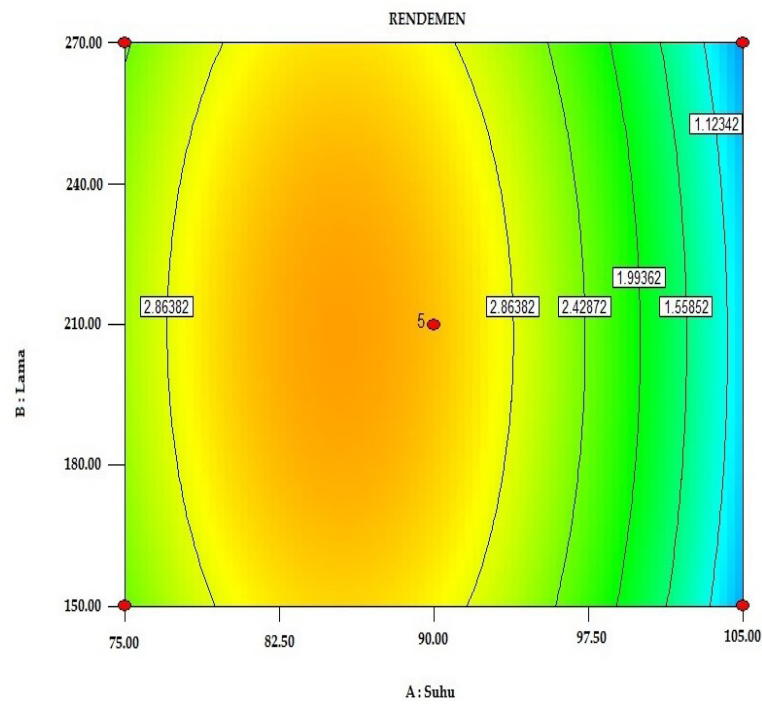

(a)

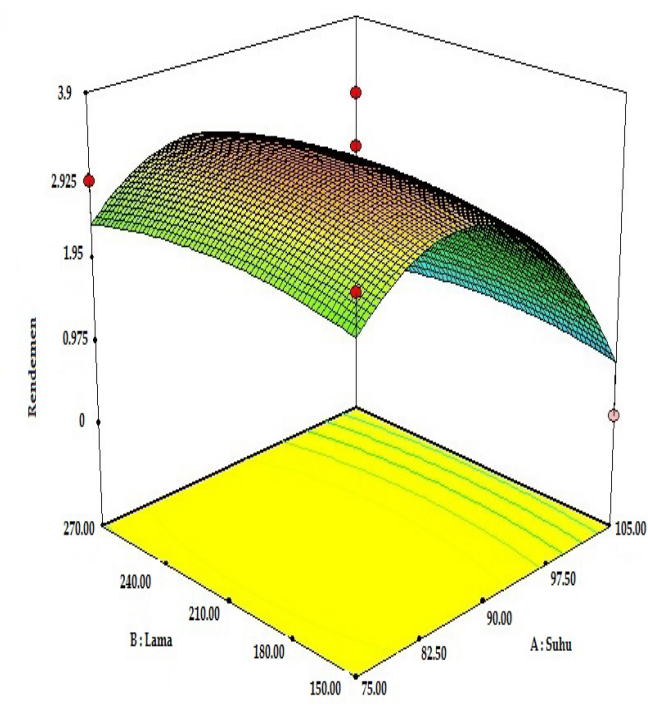

(b)

Gambar 1. Plot Kontur (a); Grafik 3D (b); pengaruh interaksi suhu dan lama ekstraksi terhadap rendemen polisakarida dari jali

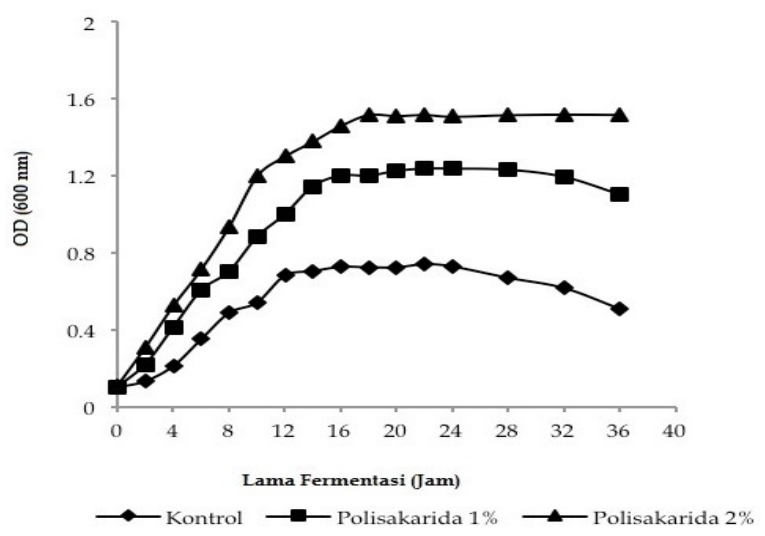

Gambar 2. Pengaruh media dengan penambahan ekstrak polisakarida jali terhadap pertumbuhan bakteri Lactobacillus casei selama fermentasi 36 jam

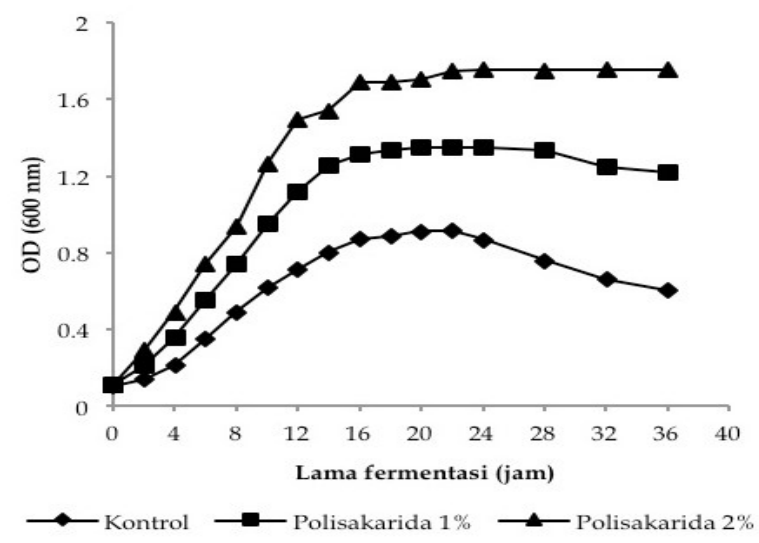

Gambar 3. Pengaruh media dengan penambahan ekstrak polisakarida jali terhadap pertumbuhan bakteri Bifidobacterium bifidum selama fermentasi 36 jam 
menunjukkan bahwa respon dipengaruhi oleh variabel membentuk parabola terbuka ke bawah. Semakin tinggi suhu maka nilai respon juga semakin tinggi, dan pada suhu tertentu nilai respon rendemen optimal, kemudian terjadi penurunan rendemen polisakarida seiring dengan peningkatan suhu.

Rendemen polisakarida akan mencapai nilai optimum pada interval suhu 82.5-97.5 ${ }^{\circ} \mathrm{C}$. Namun, jika ditinjau dari lama ekstraksi tidak terlalu terlihat penurunan maupun peningkatan rendemen polisakarida. Semakin lama waktu yang digunakan untuk ekstraksi, maka rendemen polisakarida tidak terlalu menunjukkan peningkatan.

\section{Verifikasi Hasil Optimasi Proses Ekstraksi Polisakarida Jali}

Prediksi titik optimum dan hasil verifikasi dari optimasi proses ekstraksi polisakarida dari jali pada masing-masing variabel yang tersaji pada Tabel 7. Berdasarkan prediksi, diketahui bahwa ekstraksi polisakarida dari jali secara optimum menghasilkan rendemen di titik variabel suhu dan lama ekstraksi yaitu $85.44{ }^{\circ} \mathrm{C}$ selama 207.63 menit yang akan menghasilkan nilai rendemen polisakarida sebesar 3.299\%. Namun, pada saat dilakukan verifikasi pada kondisi tersebut hasil rendemen polisakarida yang didapatkan adalah sebesar 3.286\% dengan tingkat ketepatan sebesar 99.6150\%. Tingkat ketepatan tersebut menandakan bahwa prosentase kesalahan kurang dari 5\%, maka hasil dari solusi program dapat diterima dan digunakan sebagai acuan optimasi proses ekstraksi polisakarida dari jali.

Nilai desirability pada prediksi memiliki nilai sebasar 0.8441, yang menunjukkan kondisi terbaik memiliki ketepatan hasil optimasi sebesar $84.41 \%$, sedangkan sisanya sebanyak $15.59 \%$ dapat dipengaruhi oleh kondisi lain yang tidak dapat dikontrol seperti kemurnian pelarut, kontrol suhu, ketepatan proses penyaringan, dan lainnya. Nilai desirability sebesar 0.8441 telah memenuhi persyaratan batasan desirability yaitu antara $0-1$. Hal ini menunjukkan bahwa metode ekstraksi yang dilakukan cukup efektif untuk mendapatkan rendemen ekstrak kasar polisarida dari jali yang memiliki nilai maksimum.

\section{Analisis Sifat Kimia Ekstrak Polisakarida}

Hasil analisis ekstrak serta nilai penurunannya tersaji dalam Tabel 8. Berdasarkan
Tabel 8, kandungan protein dan lemak masing-masing adalah sebesar $1.89 \%$ dan $0.04 \%$. Nilai ini diketahui menurun dari nilai protein dan lemak pada bahan baku. Hal ini disebabkan karena kandungan protein pada bahan pangan dapat terdenaturasi saat dilakukan proses pemanasan yang menyebabkan gugus hidrofobik protein keluar dan protein tersebut tidak lagi terdispersi sebagai koloid, kemudian partikel-partikel tersebut cenderung terpisah dan mengendap ketika didiamkan, sedangkan penurunan pada lemak terjadi akibat penambahan pelarut etanol untuk mendapatkan ekstrak polisakarida murni (Nugroho, 2013).

Nilai kadar polisakarida pada ekstrak memiliki nilai sebesar $25.73 \%$. Pemisahan polisakarida dari sel tanaman menggunakan air sebagai pelarut dinilai sebagai metode tradisional yang memiliki keuntungan yaitu kondisi yang stabil dan mudah dikontrol. Kandungan polisakarida yang semakin tinggi menunjukkan bahwa semakin tinggi pula bahan tersebut dijadikan sebagai sumber prebiotik, karena nutrisi pada media pertumbuhan bakteri probiotik semakin tinggi.

Nilai kandungan serat kasar pada ekstrak hasil penelitian adalah $0.07 \%$, nilai ini menurun sebanyak $93.33 \%$ yang kemungkinan terjadi karena rusaknya struktur serat kasar karena suhu tinggi yang dilakukan pada saat ekstraksi. Serat kasar merupakan senyawa bahan pangan yang tidak dapat dicerna oleh asam kuat maupun basa kuat. Serat kasar termasuk golongan karbohidrat yang mempunyai monomer glukan dengan ikatan $\beta$-glikosidik.

Ekstrak kasar polisakarida jali hasil penelitian mengandung pati rata-rata cukup tinggi yakni $10.70 \%$, namun nilai tersebut diketahui menurun dari bahan baku. Hal ini kemungkinan disebabkan pati mengalami gelatinisasi karena adanya suhu tinggi yang menyebabkan ikatan hidrogen pada pati menjadi melemah dan air terserap ke dalam granula pati. Air yang terserap ke dalam granula pati tersebut menjadi air terikat dan menyebabkan granula pati mengembang secara signifikan serta tidak dapat disaring saat proses penyaringan ekstrak. Menurut Ubwa et al. (2012), pati dari serealia umumnya mulai tergelatinisasi pada suhu $53{ }^{\circ} \mathrm{C}$. Ekstrak polisakarida murni didapatkan dengan cara menghilangkan kandungan pati dengan cara hidrolisis menggunakan enzim amilase. 
Pertumbuhan Probiotik dengan Perlakuan Penambahan Ekstrak Kasar Polisakarida Jali

Pertumbuhan probiotik ditunjukkan dengan adanya penambahan jumlah sel selama proses fermentasi berlangsung. Penambahan jumlah sel tersebut ditunjukkan dengan adanya perubahan kekeruhan pada media pertumbuhan, dari cokelat jernih kekuningan menjadi cokelat keruh, baik pada media yang dilakukan penambahan polisakarida maupun media kontrol. Semakin keruh media maka semakin tinggi jumlah bakteri yang tumbuh didalamnya.

Pada penelitian ini dilakukan penambahan ekstrak polisakarida yang bervariasi, yakni $0 \%, 1 \%$, dan $2 \%$. Hal ini bertujuan untuk mengetahui pengaruh penambahan ekstrak kasar polisakarida terhadap pertumbuhan kedua bakteri probiotik. Menurut Todar (2018), semakin tinggi jumlah nutrisi pada media pertumbuhan mikroba, maka pertumbuhan mikroba tersebut juga akan makin baik karena jumlah kebutuhan nutrisinya terpenuhi. Nutrisi tersebut terdiri dari sumber $\mathrm{C}, \mathrm{H}, \mathrm{O}, \mathrm{N}, \mathrm{S}, \mathrm{P}, \mathrm{K}, \mathrm{Mg}, \mathrm{Fe}, \mathrm{Ca}, \mathrm{Mn}$, dan beberapa trace element, seperti $\mathrm{Zn}, \mathrm{Co}, \mathrm{Cu}$, dan Mo. Kurva pertumbuhan kedua probiotik pada media dengan penambahan ekstrak polisakarida berdasarkan hasil penelitian tersaji pada Gambar 2 dan 3. Gambar 2 dan 3 pada kedua bakteri menunjukkan bahwa fase log terjadi pada jam ke-2 hingga jam ke14. Setelah jam ke-14 terjadi fase stasioner, dimana pertumbuhan bakteri cenderung tidak mengalami peningkatan dikarenakan nutrisi yang ada pada media telah habis digunakan. Berdasarkan gambar tersebut, kemungkinan fase lag terjadi antara jam ke-0 hingga sebelum jam ke-2, sedangkan fase kematian terjadi setelah jam ke-36. Menurut Mojgani dan Amirnia (2007), fase lag Lactobacillus casei RN 78 terjadi pada jam ke-0 hingga jam pertama fermentasi, kemudian fase log terjadi setelahnya hingga jam ke-8, dan dilanjutkan dengan fase stasioner hingga jam ke-18, setelah itu terjadi penurunan tingkat pertumbuhan yang menandakan terjadinya fase kematian. Perbedaan data dengan literatur ini kemungkinan disebabkan oleh perbedaan strain yang menyebabkan perbedaan kemampuan untuk menggunakan nutrisi pada media, atau perbedaan media yang digunakan.

Pertumbuhan bakteri Lactobacillus casei maupun Bifidobacterium bifidum dengan penambahan ekstrak polisakarida jali ke dalam media sebanyak $1 \%$ dan $2 \%$ meng- hasilkan kenaikan pertumbuhan yang lebih tinggi dibandingkan kontrol, hal ini disebabkan karena penambahan polisakarida dapat digunakan sebagai tambahan nutrisi bagi kedua bakteri dibandingkan kontrol. Namun pada semua perlakuan penambahan polisakarida $2 \%$ menghasilkan pertumbuhan yang paling tinggi pada kedua bakteri, hal ini dapat disebabkan karena tingginya sumber energi yang dimanfaatkan bakteri untuk menunjang pertumbuhannya.

Bakteri Lactobacillus casei dan Bifidobacterium bifidum diketahui merupakan bakteri asam laktat dan tergolong sebagai bakteri probiotik yang mampu mengkatalisis polimer-polimer karbohidrat dan memanfaatkannya sebagai sumber energi. Energi yang tercukupi akan meningkatkan laju pertumbuhan kedua bakteri tersebut, sedangkan karbohidrat sebagai sumber karbon akan terdegradasi menjadi senyawa yang lebih sederhana, seperti monosakarida atau disakarida. Selanjutnya, monosakarida tersebut akan dimetabolisme kembali oleh kedua bakteri menjadi asam-asam organik, yakni asam laktat atau asam asetat. Metabolisme karbohidrat oleh bakteri asam laktat berlangsung dengan bantuan enzim pemecah ikatan glikosidik, seperti glikosil hidrolase (Gänzle and Follador, 2012).

Menurut Azmi et al. (2012), terbentuknya asam-asam organik hasil metabolisme mikroba akan menurunkan nilai $\mathrm{pH}$ pada media fermentasi seiring dengan meningkatnya jumlah biomassa bakteri. Senyawa prebiotik yang diketahui dapat menstimulasi bakteri probiotik (Lactobacillus casei dan Bifidobacterium bifidum) dan secara tidak langsung juga akan menekan pertumbuhan mikroba patogen pada saluran pencernaan. Keberadaan asam yang tinggi akan menyebabkan mikroba patogen mengalami kematian, sedangkan bakteri probiotik akan tetap hidup karena ketahanannya yang baik terhadap jumlah asam yang tinggi.

\section{SIMPULAN}

Optimasi ekstraksi polisakarida pada jali memiliki rendemen tertinggi pada suhu $85.45{ }^{\circ} \mathrm{C}$ dan 207.63 menit, yaitu 3.29\%. Ekstrak kasar polisakarida jali ini juga diketahui berpotensi sebagai prebiotik karena 
dapat meningkatkan pertumbuhan bakteri Lactobacillus casei dan Bifidobacterium bifidum, serta dapat mempertahankan keberadaan kedua bakteri tersebut pada konsentrasi penambahan ekstrak polisakarida sebanyak $2 \%$ pada media pertumbuhan mikroba. Sifat fungsional ini apabila dikembangkan lebih lanjut akan meningkatkan daya guna dan konsumsi jali yang selama ini kurang dimanfaatkan

\section{DAFTAR PUSTAKA}

Apirattananusorn, S. 2007. Arabinoxylans from Job's Tears (Coix lachryma-jobi L.): Chemical, Molecular and Structural characterization. Disertasi. Doktor. Suranaree University of Technology. Thailand

AOAC. 2005. Official of Analysis of The Association of Official Analytical Chemistry. AOAC International

Apriyantono, A, Ferdiaz, D, Puspitasari, N, L, Sedarnawati, Budiyanto, S. 1989. Analisis Pangan. IPB Press. Bogor

Azmi, A, F, Mustafa, S, Hashim, D, M, Manap, Y, A. 2012. Prebiotic activity of polysaccharides extracted from $\mathrm{Gi}$ gantochloa levis (Buluh beting) shoots. Molecules. 17(2):1635-1651

Badan Pusat Statistik. 2011. Kajian Konsumsi dan Cadangan Beras Nasional 2011. Badan Pusat Statistik. Jakarta

Chang, C, C, Huang, L, H, Chiang, W, Hsia, S, M. 2018. Hexane fraction of adlay (Coix lachryma-jobi L.) testa ethanolic extract inhibits human uterine sarcoma cancer cells growth and chemosensitizes human uterine sarcoma cells to doxorubicin. Phytomedicine. 47:69-80

Chen, C, Zhang, Y, Gao, Y, Xu, Q, Ju, X, Wang, L. 2016. Identification and anti-tumour activities of phenolic compounds isolated from defatted adlay (Coix lachryma-jobi L. var. ma-yuen Stapf) seed meal. Journal of Functional Foods. 26:394-405

Cruz, R, T, D. 2014. Adlay: a healthy, allFilipino breakfast cereal. Dilihat 26 Juli 2016. <https://www.pressreader. com/philippines/the-philippinestar/20141228/282080570195902>

Gänzle, M, G, Follador, R. 2012. Metabolism of oligosaccharides and starch in lactobacilli: a review. Frontier Microbiology.
3:1-15

Hong, S, S, Choi, C, W, Choi, Y, H, Oh, J, S. 2016. Coixlachryside A: A new lignan glycoside from the roots of Coix lachryma-jobi L. var. ma-yuen Stapf. Phytochemistry Letters. 17:152-157

Kuo, C, C, Chen, H, H, Chiang, W. 2012. Journal of Traditional and Complementary Medicine. Adlay (the seeds of Coix lachryma-jobi L. var. ma-yuen Stapf) is a potential cancer chemopreventive agent toward multistage carcinogenesis processes. Journal of Traditional and Complementary Medicine. 2(4):267-275

Kutschera, M, Krasaekoopt, W. 2012. The use of job's tear (Coix lacryma-jobi L.) flour to substitute cake flour in butter cake. Au. J. T. 15(4):233-238

Lam K, L, Cheung, P, C, K. 2013. Non-digestible long chain beta-glucans as novel prebiotics. Bioactive Carbohydrates and Dietary Fibre. 2(1):45-64

Lu, X, Liu, W, Wu, J, Li, M, Wang, J, Wu, J, Luo, C. 2013. A polysaccharide fraction of adlay seed (Coix lachryma-jobi L.) induces apoptosis in human nonsmall cell lung cancer A549. Biochem Biophys. Res. Commun. 430(2):846-851

Mjwara, J, M, Botha, C, E, J. 1993. The interactive effects of light, temperature and $\mathrm{CO} 2 / \mathrm{O} 2$ ratios on photosynthesis of Coix lachryma-jobi L. South African Journal of Botany. 59(4):377-384

Mojgani, N, Amirnia, C. 2007. Kinetics of growth and bacteriocin production in L. casei RN 78 isolated from a dairy sample in IR Iran. International Journal of Dairy Science. 2(1):1-12

Nugroho, M. 2013. Pengaruh suhu dan lama ekstraksi secara pengukusan terhadap rendemen dan kadar albumin ikan gabus (Ophiocephalus striatus). Jurnal Saintek Perikanan. 8(2):38-43

Nurmala, T. 2011. Potensi dan prospek pengembangan jali (Coix lacryma jobi L) sebagai pangan bergizi kaya lemak untuk mendukung diversifikasi pangan menuju ketahanan pangan mandiri. Pangan. 20(1):41-48

Todar, K. 2018. Nutrition and Growth of Bacteria. Dilihat 26 Juni 2018. <http:/ / textbookofbacteriology.net/nutgro.html>

Ubwa, S, T, Abah, J, Asemave, K, Shambe, T. 2012. Studies on the gelatinization temperature of some cereal starches. International Journal of Chemistry. 4(6):22-28 
Jurnal Teknologi Pertanian Vol. 19 No. 2 [Agustus 2018] 75-84

Potensi Jali (Coix lachryma-jobi L.) Sebagai Prebiotik [Husna dkk]

Wang, X, Huang, M, Yang, F, Sun, H, Zhou, X, Guo, X, Guo, Y, Wang, X, Zhang, M. 2015. Rapeseed polysaccharides as prebiotics on growth and acidifying activity of probiotics in vitro. Carbohydrate Polymers. 125:232-240

Yu, F, Gao, J, Zeng, Y, Liu, C, X. 2011. Effects of adlay seed oil on blood lipids and antioxidant capacity in hyperlipidemic rats. Journal of the Science of Food and Agriculture. 91(10):1843-1848

Yu, L, L, Tsao, R, Shahidi, F. 2012. Cereals and Pulses: Nutraceutical Properties and Health Benefits. Wiley-Blackwell 